Article

\title{
Using a Risk Cost-Benefit Analysis for a Sea Dike to Adapt to the Sea Level in the Vietnamese Mekong River Delta
}

\author{
Vo Thanh Danh * and Huynh Viet Khai \\ Department of Agricultural, Resource and Environmental Economics, School of Economics and \\ Business Administration, Can Tho University, Can Tho City 10000, Vietnam; \\ E-Mail: hvkhai@ctu.edu.vn
}

* Author to whom correspondence should be addressed; E-Mail: vtdanh@ctu.edu.vn;

Tel./Fax: +84-710-3839-168.

Received: 24 January 2014; in revised form: 28 March 2014 / Accepted: 15 April 2014 /

Published: 28 April 2014

\begin{abstract}
The purpose of this study is to conduct an economic valuation of creating a concrete sea dike system as an adaptation measure to counter the impacts of a rise in sea level using a risk cost-benefit analysis framework. It uses an ex-ante approach with risk considerations for storms, floods, and salinity by specifying probability distribution functions in a simulation process, in order to incorporate these risk factors into the analysis. The results showed that the benefits of storms and floods avoided dominated the dike options. The benefit of salinity avoided was also valuable, with annual rice and aquaculture productivity losses avoided of USD 331.25 per ha and USD 915 per ha, respectively. This study evaluated a range of dike options to adapt to climate change in the Vietnamese Mekong Delta, showing high levels of benefits compared to costs. The larger in scale the dike system options were, the higher the expected net present values (ENPVs) were. Of the dike alternatives applicable to the Vietnamese Mekong Delta, considering the impacts of sea level rise of storms, floods and raised salinity in soil from flooding, small scale dikes that can subsequently be increased in height should be a priority choice. The sensitivity analyses showed that the ENPVs of dike options were very sensitive with changes in discount rate but were not sensitive with increases in salinized areas at all. The findings provide evidence to support the necessity of the construction of a concrete sea dike system in the Vietnamese Mekong Delta, given the context of global climate change.
\end{abstract}

Keywords: climate change; sea dike; risk CBA; Mekong Delta; Vietnam 


\section{Introduction}

Vietnam is one of five countries that may be the most seriously affected by global climate change and a consequent rise in sea level (SLR). If the sea level rises by between 0.2 and $0.6 \mathrm{~m}$, 100-200 thousand ha of Vietnamese plains will be submerged. A one-meter rise would result in 0.3 to 0.5 million ha of the Red River Delta being submerged and $90 \%$ of the Mekong Delta would be flooded. The SLR scenarios released by the Ministry of Natural Resources and Environment (MONRE) in 2009 [1] were constructed with three levels of environmental emergency in mind - a low, medium and high level. The results showed that compared to 1980-1999, on average, the SLR would measure between $28 \mathrm{~cm}$ and $33 \mathrm{~cm}$ by mid 21 th century and between $65 \mathrm{~cm}$ and $100 \mathrm{~cm}$ by 2100 .

According to the MONRE's forecast, Vietnamese Mekong Delta (VMD) provinces will be seriously affected if the sea level rises by one meter. Almost of them would lose from $25 \%$ to $50 \%$ of its land area to flooding. If rivers rise by $0.5-1 \mathrm{~m}$, the waters will reach the height of the current dike system. Due to the impact of a global rise in sea levels, $15,000-20,000 \mathrm{~km}^{2}$ of the VMD's coastal areas would be inundated - nine of its 13 provinces would be completely below water. The current sea dike system in coastal areas cannot effectively protect people and the land when storms and high tides occur at the same time. The construction of a sea dike has to be considered as a potential solution to a rise in sea level.

In May 2009, the government issued Decree No. 667/QD-TTg regarding sea dike maintenance and upgrading. The implementation program is divided into three periods: 2009-2012, 2013-2016, and 2017-2020. From 2009-2012 mangrove forests will be planted parallel to the sea dike system. From 2013-2016, the sea dike system will be upgraded and developed alongside the road network. From 2017-2020 a sluice system will be constructed so that the sea dike system can be operated for the purposes of both adapting to a SLR and for transportation. However, up to the year 2020 the sea dike system from the center of Vietnam to the south will still be an earth-built one.

The necessity of investing in a concrete sea dike system in the VMD is the subject of an ongoing policy debate in Vietnam. Some think that the government should not build a cement sea dike system for the VMD. The reason given for such a view is that a concrete sea dike system will need billions of USD of investment and will not be effective. An alternative solution is proposed, which combines policies of moving people in the affected areas during a natural disaster and adapting life in coastal areas (by increasing collective action and public awareness of the measures necessary for living with SLR). On the other hand, proponents of the sea dike system think that the VMD needs a large sea dike system, like the Netherlands, because the VMD is surrounded by sea and it faces a high risk of SLR due to global climate change. The national budget would not be sufficient for such a big investment. In summary, there are two different points of view: one is an adaptation policy; the other is a coping policy. The question of whether a sea dike system needs to exist or not needs to be answered. The VMD's agriculture-based economy would certainly be affected by a rise in sea level, and the region has to prepare for future changes. This study uses a risk cost-benefit analysis (CBA) framework to propose an economic valuation of a concrete sea dike system as an adaptation to the impacts of a rise in sea level. (Although there are other adaptation options, for example a changing crop etc., to deal 
with climate change, this study only focuses on analyzing the necessity of investing in a concrete sea dike system to partly answer the ongoing policy debate in Vietnam).

The paper is structured as follows. The next section describes background, data collection and the empirical model of the study. The following section reports the results of CBA, including the discussions of cost and benefit measurement, and its sensitivity analysis. The final section presents the conclusions and recommendations of the study.

\section{The Current Sea Dike System in the Mekong Delta}

South Vietnam has $1100 \mathrm{~km}$ of seashore, $750 \mathrm{~km}$ to the east and $350 \mathrm{~km}$ to the west. The sea dike system and salinity control dam system at the rivermouth acts as a fence to protect the land for agricultural activities such as rice planting, fruit growing, and aquaculture, etc. The main function of the sea dike system is to prevent seawater intrusion. The function of the salinity control dam system is to prevent the intrusion of salinity and to desalt the rice fields. The sea dike system is mostly constructed out of earth and, although they are constantly maintained and repaired, these dikes are very weak in the face of natural disasters such as storms and storm surges. The annual cost of maintaining the VMD's existing sea dike system requires a large central budget and a big share of local budgets.

In recent years mainland seawater intrusion has occurred on a large scale in $\mathrm{Ca}$ Mau, Soc Trang, Ben Tre, and Tra Vinh provinces. During the 2010 dry season salinity intrusion in the VMD was very serious. Upgrading the sea dike system is considered an appropriate measure to cope with these natural disasters. Table 1 indicates the demand for sea dike systems in the provinces of the VMD. A total of $1469 \mathrm{~km}$ of new dikes are needed, $438 \mathrm{~km}$ of sea dikes and 1031 of rivermouth dikes. Provinces that need a significant number of new sea dikes are Kien Giang, Ca Mau, and Tra Vinh, which need $126 \mathrm{~km}, 96 \mathrm{~km}$, and $65 \mathrm{~km}$ respectively. The total area protected by the dike system is 494,000 $\mathrm{km}^{2}$, home to around 1.5 million people. A unique characteristic of the sea dike and rivermouth dike systems in the VMD is the existing mangrove forest that protects the dike systems-this is the difference between the VMD's sea dike system and others in Vietnam.

Table 1. Projected sea dike and rivermouth dike systems in the Mekong Delta. Source: Hoi [2].

\begin{tabular}{|c|c|c|c|c|c|c|c|c|c|}
\hline \multirow{2}{*}{ Item } & \multirow{2}{*}{ Unit } & \multirow{2}{*}{ Total } & \multicolumn{7}{|c|}{ Province } \\
\hline & & & Tien Giang & BenTre & Tra Vinh & Soc Trang & Bac Lieu & Ca Mau & Kien Giang \\
\hline Total length & $\mathrm{km}$ & 1469 & 21 & 160 & 147 & 618 & 81 & 278 & 164 \\
\hline - Sea dike & $\mathrm{km}$ & 438 & 21 & 30 & 65 & 50 & 50 & 96 & 126 \\
\hline - Rivermouth dike & $\mathrm{km}$ & 1031 & - & 130 & 82 & 568 & 31 & 182 & 38 \\
\hline Natural area protected & $10^{3}$ ha & 494 & 23 & 64 & 29 & 152 & 53 & 124 & 49 \\
\hline $\begin{array}{c}\text { Total population } \\
\text { protected }\end{array}$ & $10^{3}$ persons & 1482 & 186 & 175 & 85 & 480 & 152 & 298 & 106 \\
\hline
\end{tabular}

\section{Study Location and Data Collection}

Geographically, the VMD is a flat delta with an average height of between 0.7 and $1.2 \mathrm{~m}$, apart from the northern area of An Giang province. The VMD has a population of more than 18 million 
people. It has an area of more than 4 million ha, 2.7 million ha of which is agricultural land. Annually, flooding inundates 2 million ha and affects more than 11 million people. The terrain has limitations, including: (1) the inundation of between 1.4 and 1.9 million ha of land in upstream areas; (2) the salinization of between 1.2 and 1.6 million ha of land along coastal areas; (3) the water flow upstream has been affected by climate change; (4) seasonal changes in temperature and precipitation; and (5) the impacts of SLR. Sea level rise is a serious threat to the VMD. Areas not usually permanently inundated by seawater have become so and are rendered unsuitable for agricultural production. Moreover, approximately 1.7 million ha of the region have become salinized. The five million people living in these areas cope with the salinity problem year after year. The salinized areas are in coastal provinces, including all of the following provinces: Ben Tre, Tra Vinh, Bac Lieu, and Ca Mau, a large part of Soc Trang and Kien Giang, half of Long An and Tien Giang, a small part of Hau Giang and Vinh Long, and a very small part of An Giang province. In recent years, the salinity problem has become more serious during the dry season.

The study area was Tra Vinh province. Tra Vinh province is located at the south-east end of the VMD, between Tien river (Co Chien river) and Hau river. The climate of the province is tropical monsoon. The eastern border of the province sits on the South China Sea. The province's natural area measures 223,000 ha and the seashore has a length of $65 \mathrm{~km}$. The entire coastal area of Tra Vinh is affected by high tides and seawater intrusion. Salinity and seawater intrusion begins during the dry season, starting in December and continuing to April/June. In the dry season at Co Chien station, a distance of $35 \mathrm{~km}$ from the sea, salt measures $10 \%$ (the salt level of seawater is $30 \%$ ). More than $90 \%$ of the total agricultural land area of 90,000 ha suffers from seawater intrusion. Salinity usually begins in December at Hung My, at the Co Chien river and Tra Kha, on the Hau river. The salinity peaks in April and ends in June. In the development strategy, the Socioeconomic Master Plan identified a number of investments that would be made in terms of infrastructure development including sea dike developments (see Danh [3] for more detail). Up to 2020 the following investments will be implemented in Tra Vinh: (1) Upgrading and enlarging provincial road 914 (from Dai An commune, alongside national road 53, to Hiep Thanh commune, alongside the South East Sea); (2) Building a new provincial road 915 (alongside the sea dike parallel with the Hau river). This investment (Decision No. 1457) was decided at the Tra Vinh People's Committee, 5 August 2005; (3) Building a new provincial road 915B (by upgrading along the sea dike line that runs next to Co Chien river and the South East Sea). The starting point of this road is at Hiep Thanh commune, Duyen Hai district, and it would cross the districts of Cau Ngang, Chau Thanh, and Cang Long. This road is of importance for developing the northern economic zone of Tra Vinh province; (4) Building new sea dike lines in combination with road construction parallel to the South East Sea, for the purpose of socio-economic development. Figure 1 shows a map of the dike system in Tra Vinh province. Tra Vinh lies between two big rivers: the Co Chien and Hau rivers. Along the side of these two rivers there is a dike system consisting of sea dikes and river dikes.

Data collection was conducted in Cau Ngang, Duyen Hai, Cang Long, and Cau Ke districts of Tra Vinh province. Cau Ngang and Duyen Hai districts are in coastal areas and Cang Long and Cau Ke are not. These districts were chosen to assess the impact of salinity and seawater intrusion. With the assumption that rice production in Tra Vinh has homogeneous characteristics, the production function 
with the salinity impact dummy variable as clearly described in the section of methodology allows measurement of marginal productivity loss due to salinity.

Figure 1. Sea dike and river dike systems in Tra Vinh province. Source: Socio-economic Master Plan, Tra Vinh province, 2010-2020 [4].

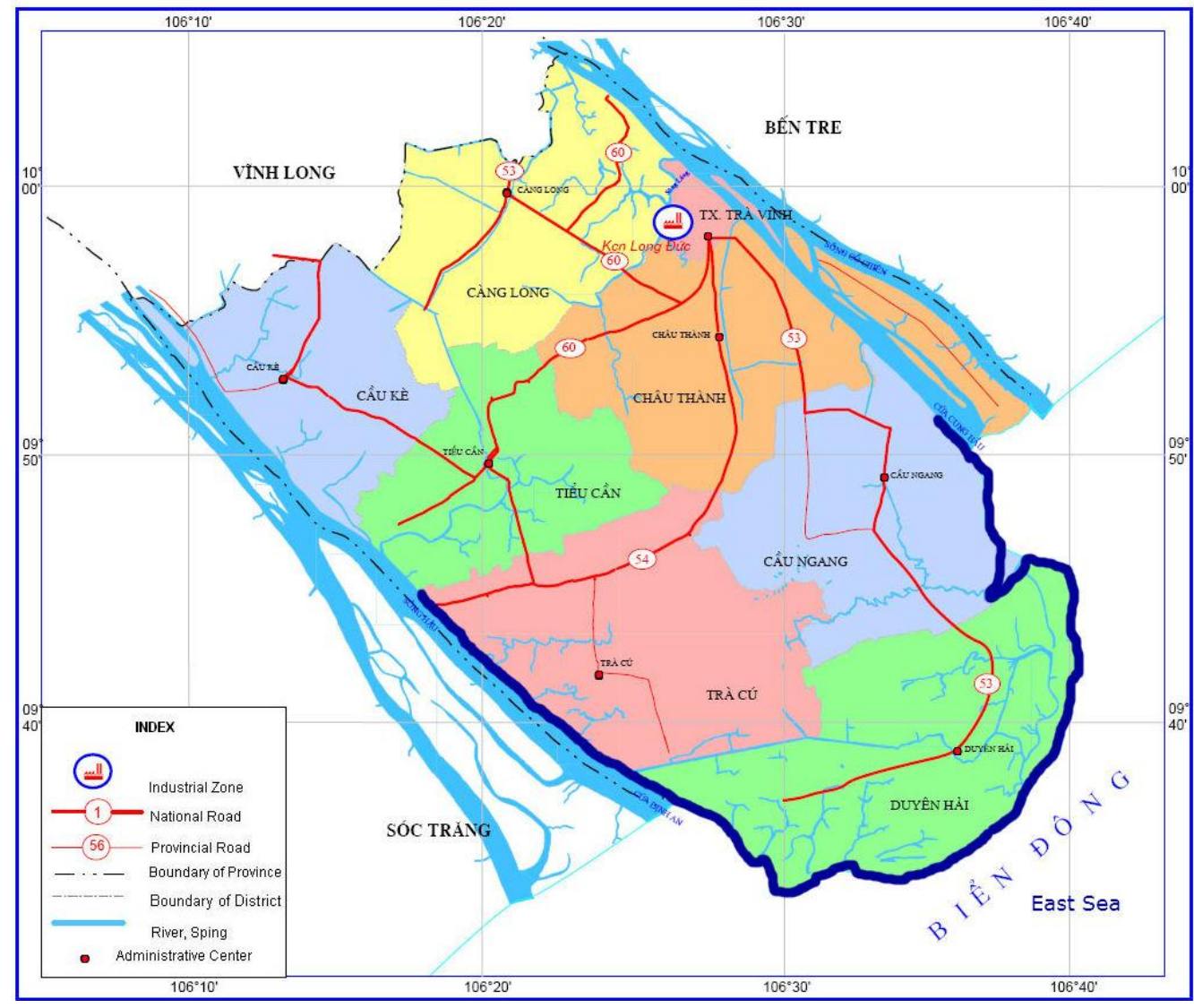

Note: The dark blue line indicates the dike system in Tra Vinh

Two hundred and thirty-three rice farmers and 79 aquaculture farmers were interviewed in the survey. Questionnaires were designed to collect appropriate data such as production area, yield, input uses (labor, fertilizer use, chemicals, food, etc.), and investment, in order to estimate lost productivity due to the effects of salinity.

In order to ascertain the impact of salinity on rice yield, the sample was split into two sub-samples - one sample of 115 rice farmers at Duyen Hai (62 farmers) and Cau Ngang (53 farmers) and another sample of 118 rice farmers at Cang Long (56 farmers) and Cau Ke (62 farmers). Rice production at Cang Long and Cau Ke is mostly unaffected by salinity but other parts of Tra Vinh province, such as Duyen Hai and Cau Ngang, have to cope with salinity and seawater intrusion. A summary of statistical variables used in the rice production model is presented in Table A1. On average, rice farmers had a high yield of 7.77 tonnes per ha and in a few cases an even higher yield of 11.5 tonnes per ha was achieved. However, rice yield from the areas affected by salinity was lower than that of areas not affected by salinity. Farmers' inputs, except for fertilizer, at the areas affected by salinity were higher, with more seed and labor inputs.

In the aquaculture survey 79 aquaculture farmers were interviewed. These farmers culture giant river prawn (macrobrachium rosenbergii). As with the rice survey, two independent survey 
areas were selected. Forty-two aquaculture farmers in Cang Long district (the salinity-free area) and 37 aquaculture farmers in Duyen Hai district (the salinity-affected area) were interviewed regarding production activities such as cultivation area, yield, inputs (seed, fish food, chemicals, labor), and investment. Questions were asked about the estimated numbers of male shrimps at harvest time and average density per $\mathrm{m}^{2}$ at culturing time; these variables play a significantly role in the yield of giant river prawn. A summary of statistical variables relating to giant river prawn production is showed in Table A2. The average yield of giant river prawn was $1153 \mathrm{~kg}$ per ha. Average yield in the area affected by salinity was $1046 \mathrm{~kg}$ per ha, compared to a yield of $1249 \mathrm{~kg}$ per ha in the area unaffected by salinity. The average density of baby shrimp was not largely different between the two areas so the different yields in the two areas were not due to density of shrimp. However, there was a difference in the production cost pattern between the two areas: the total production costs (per ha) were 77.8 million VND and 66.1 million VND in the salinity-affected and non-salinity-affected areas respectively. This shows the disadvantage of culturing giant river prawn in salinity-affected areas compared to non-salinity-affected areas-farmers in the salinity-affected areas incurred greater production costs but earned less yield.

Table 2 shows comparative analyses of revenues, production costs, and profits of these production models. Aquaculture farmers received more revenue than rice farmers - more than 3.27 times-but they had to spend up to five times more on production costs than rice farmers. Generally, aquaculture farmers earned 2.25 times more profit than rice farmers, but the profit ratio was lower than $20.38 \%$.

Table 2. Comparative analyses of revenues, costs and profits of rice and aquaculture production.

\begin{tabular}{ccc}
\hline Item & Rice Production & Giant River Prawn Production \\
\hline Revenue per ha (thousand VND) & 38,843 & 126,923 \\
- Cost per ha (thousand VND) & 14,282 & 71,576 \\
- Profit per ha (thousand VND) & 24,560 & 55,348 \\
- Profit per ha (USD) & 1228 & 2767 \\
Profit ratio (\%) & 63.23 & 43.61 \\
\hline
\end{tabular}

\section{Methodology}

In a traditional CBA, all the variables in the model are non-random and they have single values. The different possible futures and the effects of the policy on the system are assumed to be identified obviously [5].This might result in inefficient policies implicated if the future situations prove to be different than expected. Since the traditional CBA could not capture complex and dynamic systems with unpredictable states in the future, the predicted benefits and costs might not be the same as the real ones of a project [6].

To overcome the above limitation of traditional CBA, the study uses a risk CBA framework that considers the likelihood of an extreme storm event and SLR. In the risk CBA framework critical variables relating to the probability of an extreme event (storm) are random. This allows consideration of both the range of values of the variables and the way of measuring the values of variables in the context of the likelihood of an extreme storm event. To do the risk analysis, one needs 
an assessment of probability with which changes in critical variables may occur. By assigning appropriate probability distributions to the critical variables, probability distributions for the economic indicators can be estimated. For the critical variables relating to the extreme event, a binomial distribution function is built. A simulation model is then used to obtain the expected/forecasted values for the risk CBA calculations.

Following Boardman [7] and introducing the risk analysis into the CBA study, a risk assessment and cost benefit analysis framework specific to the SLR sea dike options in the VMD is described with six steps as followings:

\subsection{Step 1: Specifying the Nature of the Problem}

In this step the alternative options to concrete sea dikes need to be specified and the interested parties need to be identified. A permanent concrete sea dike system is a principal adaptation strategy for mitigating the impacts of SLR. This sea dike system runs along the coastal areas of the VMD (see Figure 1 for the dike systems in Tra Vinh province). At present, most of the existing sea dikes in Tra Vinh province are made of earth, except for one 615-m concrete sea dike at Bao village, Hiep Thanh commune, Duyen Hai district (This sea dike opened on 30 June 2010. The construction costs of this dike were VND 18.5 billion (approximately one million USD) funded by the central budget. In 2011 the remaining $700 \mathrm{~m}$ will be implemented at a cost of VND 24 billion (approximately 1.27 million USD).). In this CBA study the base scenario is the status-quo, which is no concrete sea dike.

Identifying alternatives to sea dikes depends on timing, size, and construction materials. Firstly, the time factor chosen in this study is long term - a concrete sea dike system must survive for a very long time, for instance, 100 years. The proposed lifespan of a permanent concrete sea dike network for the VMD is 100 years. Secondly, the scale of the sea dike system depends on the SLR scenario that is selected, the probability of the occurrence of an extreme storm event, and which safety standards are specified. Thirdly, the construction costs vary depending on the different types of materials chosen for the dike.

Based on the guidelines of Haasnoot et al. [8] about adaptive policy pathways for sustainable water management under uncertainty (According to Haasnoot et al.[8], the adaptation pathways with good hypothetical cases provide a valuable starting point for decision-making on policy actions.) and suggestions by Convertino et al. [9], three hypotheses regarding the scale of the sea dike system can be considered: a dike that can withstand a storm that occurs once every 20 years, one that can withstand a storm that occurs once every 50 years, and one that can withstand a storm that occurs once every 100 years. Three scales of sea dike system can be considered: the first is small in scale; the second is medium-scale; and the third is large-scale. In addition, the time frame given to the construction of the sea dike is important. Technically, the dike should be constructed in one go or in sequential periods. This study examines five different dike options associated with different scales, construction phases, and lifespans:

- Option 1: a small-scale dike $2 \mathrm{~m}$ high, lasting 50 years;

- Option 2: a medium-scale dike $3 \mathrm{~m}$ high that is constructed all in one go, with no plans for future upgrading. The lifespan of this dike is 100 years; 
- Option 3: a medium-scale dike with a height of $3 \mathrm{~m}$ that is constructed over two time periods, with the initial investment in a dike on as small a scale as option 1 (at a height of $2 \mathrm{~m}$ ) but with the body of the dike constructed on the medium scale; at the second phase of construction the dike would be upgraded to a height of $3 \mathrm{~m}$. The lifespan of this dike is 100 years;

- Option 4: a large-scale dike constructed all at once, with a height of $4 \mathrm{~m}$ and no plans for upgrading in the future. The lifespan of this dike is 100 years;

- Option 5: a large-scale dike constructed in two phases, with the initial investment of an option-1 dike (height of $2 \mathrm{~m}$ ) but with the body of the dike constructed on a large scale; at the second phase additional investment would raise the dike to $4 \mathrm{~m}$. The lifespan of the dike is 100 years.

Using a base scenario of "no concrete sea dike system" allows us to compute the differentials between with and without alternative option values. These values are the costs and benefits used in the CBA calculations.

\subsection{Step 2: Determining the Costs of Sea Dikes}

The cost of sea dikes depends on the safety standards that are adhered to and their scale. In Vietnam dike costs vary because of the differing prices of materials, land use, and revetments. The cost of labor is highly variable but constitutes a relatively small percentage of the total cost [10,11]. Because information about the cost of dikes was not available from the local dike management authority, the cost category in this study uses the dike cost calculations given by Mai et al. [11] and by Hillen et al. [10] for a typical sea dike in rural Vietnam. Mai et al. [11] determined the cost of dike heightening with a comparable probabilistic approach to ascertain the safety standards of the sea dike system. The safety standards in Mai et al. [11] are comparable to Hillen et al. [10]. The costs of dike heightening in Mai et al. are also comparable with those found by Hillen et al. [10]. Mai et al. [11] used both outer- and inner-slope protection and included the costs of maintenance in the dike costs category. Because dike costs data are estimated at different levels, in the risk CBA framework the probability distributions of the construction costs, maintenance costs, and dike heightening variables were assigned to have a uniform distribution with the minimum values of the Hillen et al. [10] estimations and the maximum values of the Mai et al. [11] estimations.

\subsection{Step 3: Determining Losses With and Without Sea Dike Alternatives}

Using sea dikes as a coastal defense avoids damage to the VMD. In this study, two types of damage were avoided: (1) loss of life, homes, infrastructure (roads, electricity network, water connections, etc.) due to storms and flooding; and (2) loss in yields of rice and aquaculture due to salinity. The measurement of each type of benefit was calculated by the methods described in the following sections:

\subsubsection{Avoidance of Storm Damage}

Storm damage can incur loss of life, homes, infrastructure (roads, electricity network, public facilities, etc.), and the destruction of rice and aquaculture production. According to the National Center for Hydrometeorological Forecasting and MONRE [1], from 1961 to 2010, 258 storms hit 
Vietnam, 17 of which were in the south of the country. While many strong storms (level 11, and above, $>103 \mathrm{~km} / \mathrm{h}$ ) have visited other parts of Vietnam, the VMD has rarely been a victim of this type of natural disaster. During this period, 43 level 11 (and above) storms hit Vietnam (or 16.7\% of the total) and nine storms (or $3.5 \%$ of the total) reached level 13 and above $(>133 \mathrm{~km} / \mathrm{h}$ ). From 1961-2010 only 17 storms, or $6.6 \%$ of the total number of storms across Vietnam, hit the MRD and only one of these storms reached level 11, with an additional one attaining level 13. The frequency of storms in the VMD follows a pattern: once every four years there is a level-6 storm $(39-49 \mathrm{~km} / \mathrm{h})$; once every 10 years there is a level $8-10$ storm $(62-102 \mathrm{~km} / \mathrm{h})$; once every 20 years there is a level-11 storm $(103-117 \mathrm{~km} / \mathrm{h})$; and once every 50 years there is a level-13 storm (>133 km/h). However, for a project as huge as the sea dike system the probability distribution of storms (and floods) needs to be simulated beyond the 1961-2010 time frame. An alternative is the World Bank's (2010) simulation of the economic losses caused by storm and flood events with different return period (RP) assumptions. The World Bank assessed economic losses caused by storms that take place once every 10 years ( $0.013 \%$ of national GDP), once every 50 years $(0.023 \%$ of national GDP), and once every 100 years (0/03\% of national GDP). The estimated economic losses caused by storms in the VMD, based on the Vietnam Central Committee for Flood and Storm Control (CCFSC) storm cost report [12], were consistent with the World Bank's estimates. For example, with the scenario of a "once every 40 years storm", the percentage of economic loss of the VMD's GDP was $0.016 \%$, compared to $0.023 \%$ for the “once every 50 years storm" scenario of the World Bank's projection. The benefit due to the avoidance of losses due to storms was estimated as follows:

$$
\text { Storm loss avoided }=\sum_{i=1}^{100} \sum_{k=1}^{5} \% \text { storm loss in } \mathrm{GDP}_{\mathrm{RP} k} \times \mathrm{GDP}_{i}
$$

where $\mathrm{RP}_{k}$ : return period $k(k=1-5), \mathrm{GDP}_{i}$ : GDP at time $i(i=1-100$, i.e., 2010-2110).

\subsubsection{Avoidance of Flood Damage}

The VMD is an area familiar with flooding. Flooding occurs frequently and brings much damage to the region. According to a CCFSC report [12], from 1991 to 2005 the VMD suffered eight floods and each one brought significant economic losses. Similar to the storm loss estimations, the flood scenarios used in this study were based on a combination of World Bank simulations [13] and calculations by the CCFSC [12]. There are four flood scenarios for the VMD: flooding once every two years; flooding once every 10 years; flooding once every 50 years; and flooding once every 100 years. The benefit due to the avoidance of losses due to flooding was estimated as follows:

$$
\text { Flood loss avoided }=\sum_{i=1}^{100} \sum_{k=1}^{4} \% \text { flood loss in } \mathrm{GDP}_{\mathrm{RP} k} \times \mathrm{GDP}_{i}
$$

where $\mathrm{RP}_{k}$ : return period $k(k=1-4)$; $\mathrm{GDP}_{i}$ : GDP at time $i(i=1-100$, i.e., 2010-2110).

\subsubsection{Reduction of Damage from Seawater Intrusion}

The production function approach is popularly applied to estimate the negative effect of environmental changes on soil erosion, deforestation, fisheries, the impact of air and water pollution on agricultural production, etc. [14,15]. There are a number of studies related to the estimation of the damage due to environmental degradation. Reddy and Behera [14] evaluated the impact of water 
pollution on rural communities in India, in terms of agricultural production, human heath, and livestock, using the effects on production, replacement costs and human capital approaches. Do and Bennett [16] used production function approach with flood duration and relative location of upstream and downstream farmers variables to estimate the cost of changing wetland management, representing the reduced income of rice production in the Mekong River Delta. The loss of rice productivity was estimated based on the differences in rice yield between upper and lower of the Tram Chim park dyke. Applying the approaches of production, cost and profit functions, Khai and Yabe [17] estimated the damage of rice production due to industrial water pollution.

Sea and river dike systems help to protect the land from seawater intrusion and salinity, which decrease yields of the rice and cash crops that are the main agricultural products of coastal areas. The benefit gained from avoiding salinity is at least the cost of building the sea dike system. Following suggestions by Do and Bennett [16] and Khai and Yabe [17], in order to measure the value of losses in agriculture and aquaculture production due to salinity, a damage function was designed. Damage was defined as a loss of productivity due to salinity. Hypothetically, as the degree of salinity increases, the productivity of rice farming and fishing decreases. Figure 2 shows the relationship between salinity and loss of productivity per unit. The total losses are the product of the marginal loss of productivity (per ha) and the area affected.

To estimate the impacts of salinity on farming yields in the affected areas, a simple production function was specified.

$$
Q_{i}=\beta_{0}+\beta_{1} L_{i}+\beta_{2} K_{i}+\beta_{3} S_{i}+u_{i}
$$

where $Q_{i}$ : yield of product $i$ (rice (tonne/ha), and giant river prawn (tonne/ha)); $L$ : labor ( $\left.\mathrm{kg} / \mathrm{ha}\right)$; $K$ : capital (fertilizer) (kg/ha); $S$ : dummy variable (1 for salinity; otherwise 0$) ; \beta_{i}$ : regression's coefficients. The Equation (3) includes two types of explanatory variables: yield-increased variables (labor and capital) and yield-decreased variables (salinity and distance).

Figure 2. The damage salinity causes to agriculture and aquaculture.

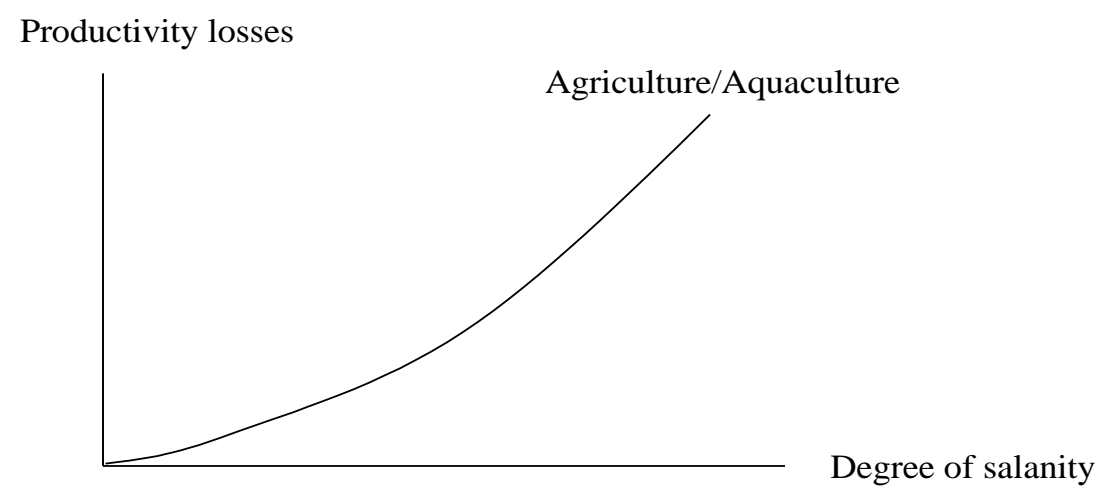

A decomposition analysis was used to measure the impact of salinity on productivity. Production function decomposition analysis allows decomposition of the difference in the change in farming productivity between land affected by salinity and land unaffected by salinity. That is, the changes are decomposed into two components: changes due to the effects of salinity, and input reallocation. A production function in a log-linear form is shown below. 
No salinity:

$$
\ln Q_{n}=\ln A_{n}+\beta_{1} \ln L_{n}+\beta_{2} \ln K_{n}
$$

With salinity:

$$
\ln Q_{s}=\ln A_{s}+\alpha_{1} \ln L_{s}+\alpha_{2} \ln K_{s}+\alpha_{3} \ln S
$$

Taking the difference between the Equations (5) and (4) and rearranging terms results in the following:

$$
\ln \left(Q_{s} / Q_{n}\right)=\ln \left(A_{s} / A_{n}\right)+\left(\alpha_{1}-\beta_{1}\right) \ln \left(L_{s} / L_{n}\right)+\left(\alpha_{2}-\beta_{2}\right) \ln \left(K_{s} / K_{n}\right)+\alpha_{3} \ln S
$$

The coefficient $\alpha_{3}$ in Equation (6) implies the marginal loss of productivity due to salinity impact separately while other coefficients, $\left(\alpha_{1}-\beta_{1}\right)$ and $\left(\alpha_{2}-\beta_{2}\right)$, show the impact of differences in labor and capital respectively. It is expected that the sign of coefficient $\alpha_{3}$ will be negative in the estimation.

The benefit of avoiding the negative impact of salinity, thanks to a dike system, is measured as follows:

$$
\text { Salinity loss avoided }=\text { marginal productivity loss } \times \text { total areas affected }
$$

In the study, in order to assess the impact of salinity on the efficient use of inputs, a regression analysis taking into account interaction effects between dummy salinity variables and input variables was applied. The OLS estimations of the rice model's regression and the aquaculture model's regression respectively are performed in Tables A3 and A4. To estimate the marginal productivity losses in Equation (7), changes in rice yield and giant river prawn yield due to salinity were derived from a salinity dummy-introduced production function. The OLS estimations in the without-interaction-effect columns in Tables A3 and A4 show the values of marginal productivity losses due to salinity. These values imply that if salinity is present the rice yield and giant river prawn yield decrease at 1.33 tonnes per ha and $183.64 \mathrm{~kg}$ per ha respectively.

\subsection{Step 4: Calculating Probability Distribution and Risk Analysis of the Critical Variables}

The risk analysis in Step 4 is central to the risk CBA framework. Methodologically, a risk CBA not only considers the range of values of the variables but also attaches to these values a measure of the likelihood of their occurrence. Two uncertainty variables need to be taken into account in the sea dike projection: storms and flooding. Estimation of these critical values must be implemented via the risk analysis framework. In this study, a simulation analysis is applied to obtain the expected values of these uncertainty variables.

In the VMD storms are not an annual weather phenomenon-they occur rarely in the region. However, when storms do happen, losses are usually large. Global climate change would suggest that in the future storms will be stronger and will move further to the south [1]. As storms are a discrete variable, a certain probability distribution function is specified in order that, based on the type of probability distribution function, a simulation model can be run to estimate the expected value of the critical variable. Storm records for 1961-2010 were used to predict the form of probability distribution. Five return periods were specified with a binomial probability distribution function for the storm variable: once every four years, once every 10 years, once every 20 years, once every 50 years, 
and once every 100 years. The value of economic damage associated with each storm frequency was estimated by simulation analysis using Crystal Ball ${ }^{\circledR}$ software.

In contrast, flooding in the VMD is usually riverine in nature, rather than flash flooding, as in other parts of Vietnam. Flooding in the VMD causes significant economic damage. Four flood scenarios were selected: once every two years, once every 10 years, once every 50 years, and once every 100 years. In order to estimate the expected values of this critical variable, a binomial probability distribution function was used. Similarly, the values of economic damage associated with each flood frequency were estimated by simulation analysis using Crystal Ball ${ }^{\circledR}$ software.

The exact costs of dike construction and dike heightening are unknown. Some studies (Hillen et al. [10]; Mai et al. [11]) have estimated the typical costs for a typical sea dike in Vietnam but differences in technical specifications, location, region, etc., make accurate costs of dike construction and heightening problematic. In order to overcome these estimation difficulties, expected values have been calculated using Crystal Ball ${ }^{\circledR}$ software based on the assumption of a uniform probability distribution function, with maximum and minimum values given.

Finally, the area of agricultural land affected by salinity cannot be accurately measured. At Tra Vinh more than $90 \%$ of the total agricultural land area is affected by salinity [4]. However, the salinity status of other salinity-affected regions differs. Therefore, estimating the area affected by salinity needs to be done with the uncertainty condition. In this study, a uniform probability distribution form is assigned for this variable using Crystal Ball ${ }^{\circledR}$ software to predict the percentage of agricultural land area affected by salinity.

\subsection{Step 5: Calculating the Attractiveness of the Sea Dike Alternatives}

In this step all positive and negative impacts are calculated in monetary terms. A social discount rate of $3 \%$ is assigned to calculate the ENPV for all benefits and costs at different times.

The main purpose of the sea dike system is to protect the region from the impacts of a rise in sea level-impacts that are being felt now, as well as impacts that may occur in the future. Therefore, predictions or projections about what will happen in the next 10, 20, or 30 years, are extremely important to this study. In order to construct the baseline for the risk CBA assessment, the study uses secondary data from Tra Vinh's Master Plan for 2010-2020 [4] and also the 2025 Vision. Based on the projections in the Master Plan, further calculations for 2030 will be done in order to construct a baseline for 2010-2030. It is proposed that a simple regression model be used for calculating forecasted indicators. The most important parameter that needs to be forecast is the GDP values of the areas bounded by the dike system. It is plausible that the whole of Tra Vinh province could be protected by the river dike and sea dike systems (see Figure 1). The values of flood and storm losses avoided are based on the proportion of losses per GDP value (see the Equations (1) and (2)). Based on the development indices shown in the Tra Vinh Master Plan, the forecast situations for 2010-2110 are presented in Table A5. 


\subsection{Step 6: Choosing the Best Sea Dike Alternative}

Based on the project evaluation criteria, the best sea dike alternative from the options will be proposed. Before the final recommendations are made to policy makers a further sensitivity analysis will be conducted.

\section{Results and Discussion}

\subsection{Cost Measurement}

\subsubsection{Dike Construction Costs}

Five dike options were considered in this risk CBA study. Construction costs and maintenance costs were projected across all the options but the costs of dike heightening were only applied to options 3 and 5 . The estimations of dyke costs were based on the dike cost projections in Hillen et al. [10] and Mai et al. [11]. (Hillen et al. [10] determined the costs of dike construction using data from local dike departments, from the cost data of stretches of newly constructed sea dikes, and from interviews with dike departments, ministries and academic staff of the Hanoi Water Resources University). According to Hillen and Mai, construction costs include the cost of creating the body of the dike, land use, berm, and outer protection and inter protection or revetments. These construction costs vary because of the differing costs of materials and land use, and the application of inner and outer protection or revetments. Although labor costs are important, they were relatively small in the overall scheme of dike construction costs (Please note that in these two studies dike construction costs were projected for the dike system in rural areas).

\subsubsection{Dike Maintenance Costs}

The annual dike maintenance cost comprises a small amount of total dike capital budgeting. Based on the dike department and ministry budgets, Hillen et al. [10] estimated the yearly dike maintenance cost for 1 kilometer of dike as USD 27,000. The construction costs and maintenance costs of dikes at the heights estimated by Hillen et al. [10] and Mai et al. [11] are showed in Table A6.

\subsubsection{Dike Heightening Costs}

In order to calculate the dike heightening costs at the second phase for options 3 and 5, the unit cost price standards given by IPCC CZMS (1990), cited by Hillen et al. [10], are applied in this study. Since most of the sea dikes in the VMD, and in Tra Vinh province in particular, are in rural areas, the dike heightening costs chosen for calculations in this study were in the range of USD 0.702-1.404 million per kilometer. (See for more detail in Table A7 that shows the unit cost prices of coastal defenses with the assumption of "all-in" costs for dike construction by Hillen et al. [10])

\subsection{Cost Simulations}

One of the problems of estimating the cost of building sea dikes is a lack of reliable data-some adjustments in calculations need to be made to compensate for this. Cost estimations by 
Hillen et al. [10] and Mai et al. [11] were dependent on various assumptions regarding safety standards and the frequency of natural disasters such as storms and floods. These assumptions vary under different uncertainty conditions. The cost estimations by Hillen et al. [10] were lower than those of Mai et al. [11]. Based on this, the probability distributions of construction costs, maintenance costs, and the costs of dike heightening were assigned uniform distributions with minimum values and maximum values. The simulation values of the cost variables with standard distribution used in the CBA calculations are presented in Table A8.

Some assumptions regarding the longevity of the dikes were made for each option: option 1 assumed a life of 50 years and all the other dikes were assumed to have a life of 100 years. In the case of dike heightening, after a period of 20 years the dikes in options 3 and 5 were heightened to the level of the dikes in options 2 and 4, respectively. With total length of the dikes in Tra Vinh province of $147 \mathrm{~km}$, the total costs of the proposed dike options are estimated in Table A9.

Having been simulated, these dike cost values were used to calculate the present values of dike options. Table 3 shows a summary of results of present values of dike costs with a discount rate at $3 \%$ and a timeline of 100 years. Results showed that option 4 had the highest cost, at USD 666.492 million, and option 1 had the lowest cost, at USD 361.893 million. Generally, the dike options that included the flexibility to heighten the dikes at a later date incurred higher costs.

Table 3. Costs of dike options (discount rate $=3 \%$, unit: million USD).

\begin{tabular}{ccccc}
\hline Dike Option & Construction Cost & Maintenance Cost & Heightening Cost & Total Cost \\
\hline Option 1 & 268.99 & 92.901 & - & 361.893 \\
Option 2 & 339.57 & 92.901 & - & 432.471 \\
Option 3 & 219.03 & 92.901 & 85.460 & 397.391 \\
Option 4 & 480.69 & 185.802 & - & 666.492 \\
Option 5 & 219.03 & 142.062 & 171.734 & 532.825 \\
\hline
\end{tabular}

\subsection{Benefit Measurement}

Avoided storm, flood and productivity losses were the major categories of benefits. Tables 4 and 5 show the economic losses for corresponding return periods for Vietnam and the VMD respectively. First, in order to estimate the benefit of storm losses avoided, the study assigned five return periods for storms: once every four years, once every 10 years, once every 20 years, once every 50 years, and once every 100 years. The first three scenarios were used in Table 5 and the last two scenarios were used in Table 4. Second, in order to estimate the benefit of flood losses avoided, the study assigned four flood scenarios in the VMD: once every two years, once every 10 years, once every 50 years, and once every 100 years. The first two scenarios were used in Table 5 and the last two scenarios were used in Table 4. Third, productivity losses avoided were derived from Appendixes 4 and 5 for rice and aquaculture respectively. In order to forecast the values of productivity losses avoided, a uniform distribution form was assigned for the salinity-affected area variable. Using the probabilities of disaster events and their corresponding damage, the values of the economic loss per event were measured. Results showed that the benefits of avoiding storm losses for corresponding return periods measured via percentage per GDP were $0.000004 \%, 0.013 \%, 0.005 \%, 0.023 \%$ and $0.027 \%$, respectively. By the 
same method, the benefits of floods avoided for corresponding return periods were $0.006 \%, 0.037 \%$, $0.026 \%, 0.033 \%$ respectively.

Table 4. Probability of flood and storm losses for the whole of Vietnam. Sources:

(a) World Bank [13]; (b) author's calculation.

\begin{tabular}{|c|c|c|c|c|}
\hline \multirow{3}{*}{ Return Period } & \multicolumn{4}{|c|}{ Indicative Annual Aggregate Probable Maximum Loss, 2008 GDP } \\
\hline & \multicolumn{2}{|r|}{ Flood } & \multicolumn{2}{|r|}{ Typhoon } \\
\hline & $\begin{array}{c}\text { Value }^{(\mathbf{a})} \\
\text { (USD Million) }\end{array}$ & Percentage Per GDP ${ }^{(b)}(\%)$ & $\begin{array}{c}\text { Value }^{(a)} \\
\text { (USD Million) }\end{array}$ & Percentage Per GDP ${ }^{(b)}(\%)$ \\
\hline 10 years & 1,093 & 0.013 & 1,095 & 0.013 \\
\hline 50 years & 2,225 & 0.026 & 1,913 & 0.023 \\
\hline 100 years & 2,781 & 0.033 & 2,290 & 0.027 \\
\hline
\end{tabular}

Table 5. Probability of flood and storm losses for the Mekong Delta. Source: CCFSC [12] and author's calculation.

\begin{tabular}{|c|c|c|c|}
\hline Storm/Flood & Storm (mil. VND) & Flood (mil. VND) & Frequency \\
\hline Linda storm 1997 & $7,179,615$ & - & $1 / 50$ \\
\hline Storm 1998 & 317,055 & - & $1 / 20$ \\
\hline Tropical depression 1999 & 300 & - & $1 / 4$ \\
\hline Flood 1996 & - & $2,571,223$ & $1 / 10$ \\
\hline Flood 1994 & - & $2,283,858$ & $1 / 10$ \\
\hline Flood 2001 & - & $1,535,910$ & $1 / 10$ \\
\hline Flood 1991 & - & 590,000 & $1 / 2$ \\
\hline Flood 2002 & - & 456,831 & $1 / 2$ \\
\hline Flood 1995 & - & 383,752 & $1 / 2$ \\
\hline Flood 2000 & - & 302,069 & $1 / 2$ \\
\hline Flood 1997 & - & 67,496 & $1 / 2$ \\
\hline Average loss per year: & $2,498,990$ & $1,023,892$ & \\
\hline in million USD & 138.83 & 56.88 & \\
\hline$\%$ loss in regional GDP ${ }^{\text {a }}$ & 0.037 & 0.018 & \\
\hline \multicolumn{4}{|l|}{$\%$ loss per event in regional GDP ${ }^{\mathrm{a}}$ : } \\
\hline Storm once every four years & 0.000004 & - & \\
\hline Storm once every 20 years & 0.005 & - & \\
\hline Storm once every 40 years & 0.106 & - & \\
\hline Flood once every two years & - & 0.006 & \\
\hline Flood once every 10 years & - & 0.037 & \\
\hline
\end{tabular}

To calculate the monetary values of storm losses avoided and flood losses avoided, the disaster losses in terms of percentage of GDP were multiplied by the corresponding GDP values projected in the baseline scenario (Table A5). To measure the monetary values of salinity damages avoided, the values of marginal productivity losses for rice and for aquaculture were multiplied by the salinized areas projected in the baseline scenario and the simulation value of $83 \%$ of areas invaded by salinity. While the cash flow for storms and floods were assumed at the end of the period of the events, the cash 
low for salinity takes the form of annuities. The monetary benefits of the different dike options over different periods of time, classified by storms, floods, and salinity are presented in Table A10.

Once they had been measured, the values of losses for each event (storms, floods, and salinity) were used to calculate the present values of benefits in the CBA calculation. Table 6 shows a summary of the results of the present values of the benefits of dikes, with a discount rate of $3 \%$ and a timeline of 100 years. The results showed that options 4 and 5 had the highest benefits, of USD 23,875 million, and option 1 had the lowest benefit, of USD 18,797 million.

Table 6. Present values of the benefits of the different dike options (discount rate $=3 \%$, units: million USD).

\begin{tabular}{ccccc}
\hline Dike Options & Storm Losses Avoided & Flood Losses Avoided & Salinity Losses Avoided & Total Benefit \\
\hline Option 1 & $10,509.2$ & $7,192.8$ & $1,094.6$ & $18,796.7$ \\
Option 2 & $11,759.6$ & $8,721.1$ & $1,094.6$ & $21,575.3$ \\
Option 3 & $11,759.6$ & $8,721.1$ & $1,094.6$ & $21,575.3$ \\
Option 4 & $12,789.3$ & $9,991.0$ & $1,094.6$ & $23,874.9$ \\
Option 5 & $12,789.3$ & $9,991.0$ & $1,094.6$ & $23,874.9$ \\
\hline
\end{tabular}

\subsection{Cost-Benefit Analysis}

Cost estimations (Table 3) and benefit estimations (Table 6) under uncertainty conditions are jointly presented in Figure 3. Based on the NPV decision rule, the results indicated that all the dike options could be recommended as appropriate dike adaptation measures. The larger in scale the dike systems were, the higher the ENPVs were. Among the dike alternatives applicable to the VMD, the initially small-scale dike options (options 3 and 5) that have subsequent heightening as a built-in feature are the most appropriate choices if the impacts of rises in sea level are mainly storms, floods, and increased salinity.

Figure 3. Cost-benefit analysis of sea dike options with uncertainty conditions (discount rate $=3 \%$ ).

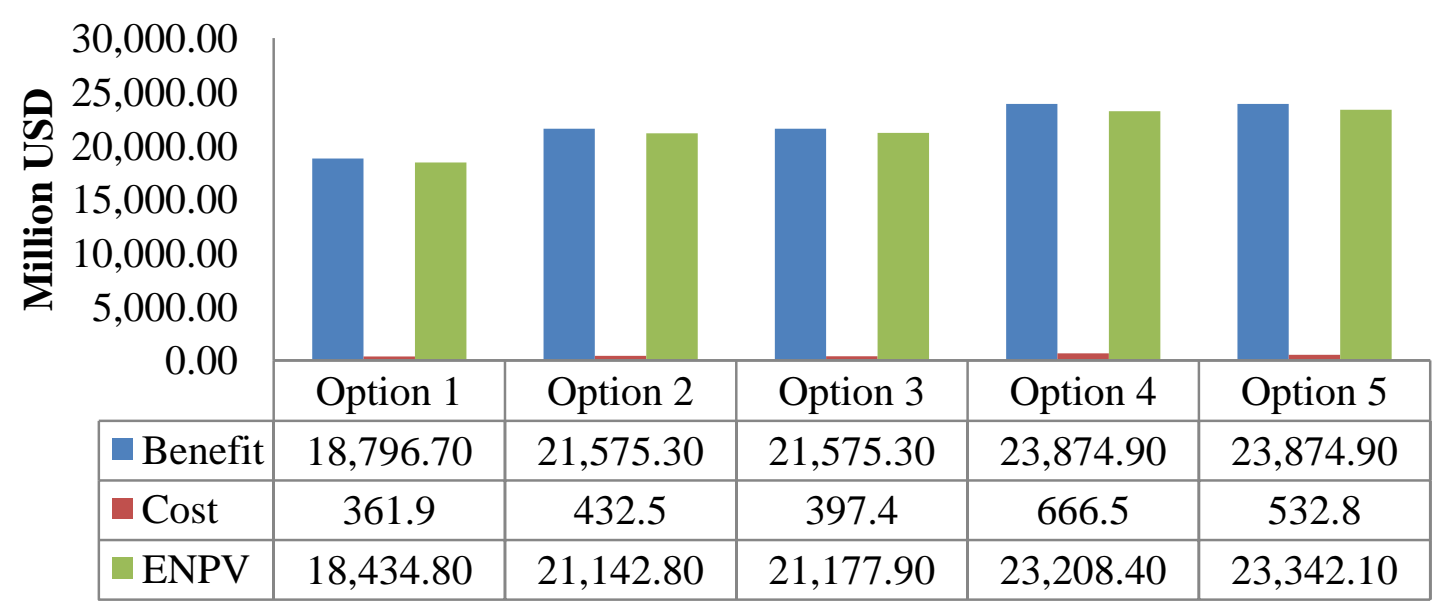




\subsection{Sensitivity Analysis}

Although estimations of costs and benefits were done under the uncertainty of storms, floods, and the state of salinity, changes that are not predictable in the impact levels of these factors could affect the CBA results. In order to ensure that the selected sea dike options were assessed at the appropriate levels, the sensitivity analyses of negative changes in discount rate and salinity were prepared in this section.

\subsubsection{Change in Discount Rate}

As the selected discount rate for a CBA calculation increases, the present values decrease. This causes changes in ENPV that provide benchmarks for selecting the best dike options. Figure 4 shows the CBA results in terms of present values of costs, present values of benefits, and ENPVs respectively if the discount rate is $6 \%$. The results showed that the ENPVs of dike options were very sensitive to an increase in discount rate. The uncertainty of the socio-economic environment is a potential factor leading to changes in discount rate.

Figure 4. Cost-benefit analysis of sea dike options with uncertainty (discount rate $=6 \%$ ).

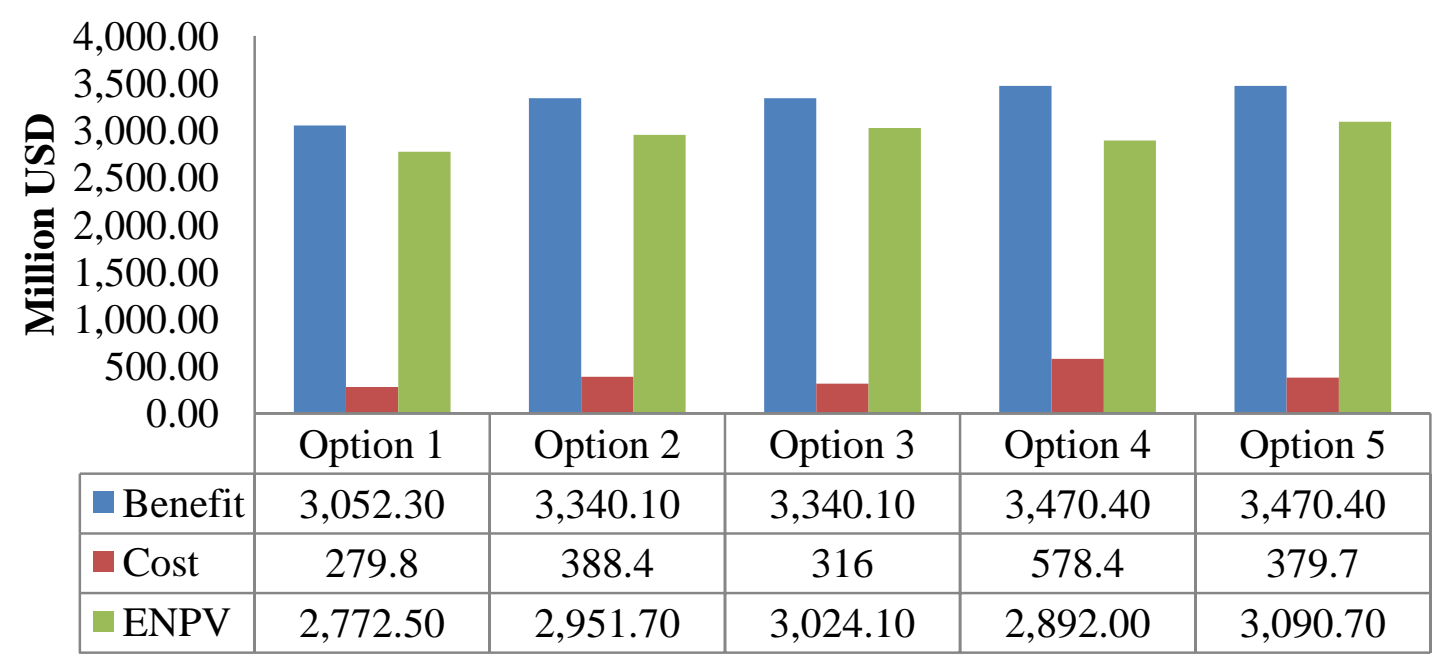

\subsubsection{Change in Salinized Areas}

The CBA calculations showed that productivity losses avoided provided the highest proportion of total benefits. Values from salinity-affected areas were used to project values for all rice and aquaculture land. According to the Socio-economic Master Plan of Tra Vinh province, more than $90 \%$ of the total natural area of the province could become salinized [4]. The natural area currently affected in six permanently-salinized regions is about $75 \%$. It is reasonable to assume that these salinity-affected areas depend on the effectiveness of the river dike and sea dike systems. In order to assess the effect of this important variable on the ENPVs, a further analysis was conducted. Figure 5 shows the present values of the benefits of ENPVs, assuming that $50 \%$ of the rice and aquaculture land is salinized. The sensitivity analysis showed that compared to the initial CBA assessment, the ENPVs were still robust. 
Figure 5. Cost-benefit analysis of different dike options with sensitivity analysis (discount rate $=3 \%$, salinized areas $=50 \%$ ).

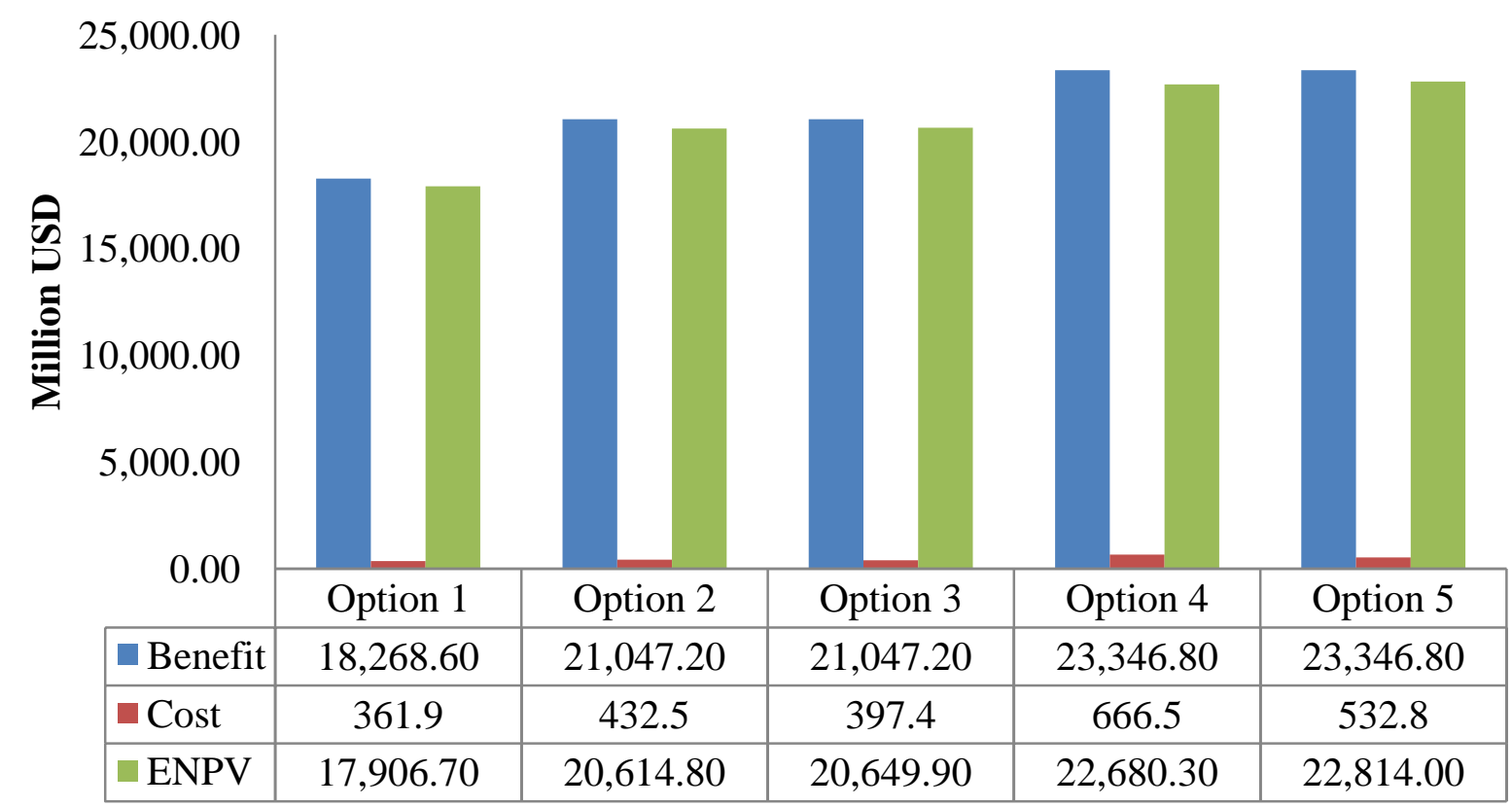

\section{Conclusions and Recommendations}

The study used the risk CBA framework to assess the dike options proposed for the VMD. There were three cost components in the cost category: construction costs, maintenance costs, and dike heightening costs. The benefit category was defined as economic damage avoided in the VMD because of the protection offered by the dike system. The results showed that applying option 4 to the entire length of the dike system $(147 \mathrm{~km})$ incurred the highest present value (PV) of USD 666.5 million. Option 1 had the lowest PV costs, at USD 361.9 million. In general, dike options with built-in subsequent heightening incurred lower PV costs than alternative options that built to full height from the start. The results also showed that the benefits of losses avoided due to storms and floods were important. In the case of salinity, annual rice and aquaculture productivity losses avoided were USD 331.25 per ha and USD 915 per ha respectively. Based on the NPV decision rule, results indicated that all the dike options should be taken into account if dike adaptation measures were to be considered for the VMD. The larger in scale the dike systems were, the higher the ENPVs were. Of the dike alternatives applicable to the VMD, the small-scale dike options - option 1, options 3 and 5-should be chosen as the impacts of sea level rise focus on storms, floods, and salinity. Following the CBA framework, sensitivity analyses of negative changes in discount rates and salinity impacts were conducted to assess the robustness of the projected dike options. First, the results showed that the ENPVs of dike options were very sensitive to changes in discount rate. Second, if the salinity-protected area is $50 \%$ of the total land area, the CBA results were not significantly altered.

It should be noted that the dike options in this study focused on economic valuations of storms, floods, and salinity. Other factors, such as the cost/value of loss of life, the cost/value of wetland protection, and the cost/value of planting mangrove forest to protect dikes, etc., were not calculated in the CBA analyses. Although arguments regarding the feasibility of a concrete sea dike system for 
coping with climate change impacts are still the subject of policy debates, the CBA results in this study have found initial evidence to support the construction of a concrete sea dike system for the VMD.

Based on the CBA analysis of projected sea dike options, the study gives some recommendations as follows. Firstly, the construction of sea dikes in the VMD as an adaptation measure to climate change is a suitable response. Secondly, since the effects of climate change are uncertain, climate change-related projects such as sea dike options should be appraised within a risk CBA framework. If a traditional CBA model is applied, the measurement of losses will not be appropriate. Thirdly, if the proposed sea dike options in this report are taken into consideration, the existing national sea dike upgrading program would need to be revised as a concrete sea dike system with a century-long lifespan rather than a working life of 2020-2030. Although such a concrete sea dike system would be more expensive than the existing sea dike program, the benefits demonstrate that it deserves to be considered. Fourthly, if the sea dike options in this report are to be seriously considered, then the establishment of initially small-scale dike systems would be the most appropriate option for the VMD. Finally, sea dike options in this study were assessed mainly on the impacts of storms, floods, and salinity while other factors such as dike failure, lives lost, wetland protection, the benefits of mangrove forest protecting dikes, etc., were not measured. Therefore, in the next sea dike-related study, these important factors need to be considered in the calculations.

\section{Acknowledgments}

The authors are grateful to Herminia Francisco, a director of the Economy and Environment Program for Southeast Asia (EEPSEA), for her support for the study. We would like to express our sincere gratitude to Benoit Laplante, an economist at the World Bank, and two anonymous reviewers for their invaluable comments, which led to significant improvement of the manuscript. Our warmest thanks go to EEPSEA for sponsoring the study.

\section{Author Contributions}

Vo Thanh Danh designed the study questionnaire, collected and analyzed the data, and drafted the manuscript. Huynh Viet Khai made critical revisions to the manuscript. All authors read and approved the final manuscript.

\section{Conflicts of Interest}

The authors declare no conflict of interest.

\section{References}

1. Ministry of Natural Resources and Environment. Climate change, sea level rise scenarios for vietnam; Ministry of Natural Resources and Environment: Hanoi, Vietnam, 2009.

2. Hoi, T.N. Recovering and Upgrading the Sea Dike System in the Vietnamese Mekong Delta. Available online: http://www.clst.sc.vn/AP/tapchitrongnuoc/hdkh/1999/so10/6.htm (accessed on 20 March 2008). 
3. Danh, V.T. Adaptation to Sea Level in the Vietnamese Mekong River Delta: Should a Sea Dike be Built?; EEPSEA Report 2011-RR13; EEPSEA (The Economy and Environment Program for Southeast Asia): South Bridge Court, Singapore, 2011.

4. The Tra Vinh People's Committee. Tra vinh's master plan for 2010-2020; The Tra Vinh People's Committe: Tra Vinh, Vietnam, 2008.

5. Walker, W.E.; Rahman, S.A.; Cave, J., Adaptive policies, policy analysis, and policy-making. Eur. J. Oper. Res. 2001, 128, 282-289.

6. Yzer, J. Adptive Policies: A Way to Improve the Cost-Benefit Performance of Megaprojects? Master Thesis, Delft University of Technology, Delft, The Netherlands, 2011.

7. Boardman, A.E.; Greenberg, D.H.; Vining, A.R.; Weimer, D.L. Cost-Benefit Analysis: Concepts and Practice; Prentice House: Ashland, WI, USA, 2001.

8. Haasnoot, M.; Kwakkel, J.H.; Walker, W.E. Designing Adaptive Policy Pathways for Sustainable Water Management under Uncertainty: LESSONS Learned from Two Cases. In Proceedings of the Third International Engineering Systems Symposium, Delft, The Netherlands, 18-20 June 2012.

9. Convertino, M.; Foran, C.M.; Keisler, J.M.; Scarlett, L.; LoSchiavo, A.; Kiker, G.A.; Linkov, I. Enhanced Adaptive Management: Integrating Decision Analysis, Scenario Analysis and Environmental Modeling for the Everglades; Macmillan Publishers Limited: London, UK, 2013.

10. Hillen, M.M.; Jonkman, S.N.; Kanning, W.; Kok, M.; Geldenhuys, M.A.; Stive, M.J.F. Coastal Defence Cost Estimates Case Study of The Netherlands, New Orleans and Vietnam; Delft University of Technology: Delft, The Netherlands, 2010; p. 59.

11. Mai, V.C.; Tri, M.C.; Quy, N.B.; Vrijling, J.K., Risk-based approach for safety standard of coastal flood defences in vietnam. J. Water Resour. Environ. Eng. 2008, 23, 204-217.

12. The Ministry of Agriculture and Rural Development. The vietnam central committee for flood and storm control (ccfsc) report; The Ministry of Agriculture and Rural Development: Hanoi, Vietnam, 2009.

13. The World Bank. Weathering the storm: Options for disaster risk financing in vietnam; The World Bank: Washington, DC, USA, 2010.

14. Reddy, V.R.; Behera, H. Impact of water pollution on rural communities: An economic analysis. Ecol. Econ. 2006, 58, 520-537.

15. Khai, H.V.; Yabe, M. Rice yield loss due to industrial pollution in Vietnam. J. US-China Public Adm. 2012, 9, 248-256.

16. Do, T.N.; Bennett, J. Would Wet Biodiversity Conservation Improve Social Welfare? A Case Study in Vietnam's Mekong River Delta. In Proceedings of the GMSARN International Conference on Sustainable Development: Challenges and Opportunities for GMS, 12-14 December 2007, Pattaya, Thailand.

17. Khai, H.V.; Yabe, M. Impact of Industrial Water Pollution on Rice Production in Vietnam. In International Perspectives on Water Quality Management and Pollution Control; Quinn, N.W.T., Ed.; InTech Publishing: Rijeka, Croatia, 2013; pp. 61-85. 


\section{Appendix}

Table A1. Summary of statistical variables in the rice production model.

\begin{tabular}{ccccc}
\hline Item & Mean & Max & Min & Std. Dev. \\
\hline Whole sample $(n=233)$ & & & & \\
\hline - Area (ha) & 2.03 & 26.00 & 0.10 & 2.69 \\
- Yield (tonne/ha) & $7,768.54$ & $11,500.00$ & $4,630.00$ & $1,022.76$ \\
- Seed (kg/ha) & 157.79 & 620.00 & 17.00 & 62.65 \\
- Labor (day/ha) & 30.60 & 94.90 & 3.00 & 13.04 \\
- Fertilizer (kg/ha) & 453.06 & $3,129.00$ & 31.00 & 235.01 \\
\hline Salinized sample ( $(\mathrm{h}=115)$ & & & & \\
\hline - Area (ha) & 1.79 & 10.00 & 0.26 & 1.79 \\
- Yield (tonne/ha) & $7,088.20$ & $9,105.00$ & $4,630.00$ & 718.52 \\
- Seed (kg/ha) & 163.26 & 620.00 & 17.00 & 67.81 \\
- Labor (day/ha) & 32.38 & 79.28 & 13.33 & 12.29 \\
- Fertilizer (kg/ha) & 430.02 & $1,040.00$ & 31.00 & 161.34 \\
\hline Unsalinized sample ( $n=118)$ & \multicolumn{5}{c}{} \\
\hline - Area (ha) & 2.26 & 26.00 & 0.10 & 3.33 \\
- Yield (tonne/ha) & $8,431.58$ & $11,500.00$ & $6,639.20$ & 820.27 \\
- Seed (kg/ha) & 152.45 & 370.00 & 18.25 & 56.96 \\
- Labor (day/ha) & 28.87 & 94.90 & 3.00 & 13.56 \\
- Fertilizer (kg/ha) & 475.52 & $3,129.00$ & 175.00 & 288.30 \\
\hline
\end{tabular}

Table A2. Summary of statistical variables in the aquaculture model.

\begin{tabular}{ccccc}
\hline Item & Mean & Max & Min & Std. Dev. \\
\hline Area (ha) & Whole sample $(n=79)$ & & & \\
Yield (kg/ha) & 1.33 & 13.00 & 0.30 & 1.62 \\
\hline Numbers of male shrimp (\%) & $1,153.85$ & 3,500 & 300 & 517.73 \\
Average density per m ${ }^{2}$ (shirmp) & 53.61 & 90 & 27 & 14.94 \\
Industry food (tonne/ha) & 14.34 & 25 & 7 & 4.96 \\
Costs: & 3.22 & 7.40 & 0.79 & 1.49 \\
- Dam cost per ha (thousand VND) & $9,792.48$ & 45,346 & 589 & 8,367 \\
- Seed cost per ha (thousand VND) & $17,131.58$ & 34,365 & 1,715 & 8,357 \\
- Food cost per ha (thousand VND) & $34,746.96$ & 77,871 & 737 & 23,478 \\
- Chemical cost per ha (thousand VND) & $4,844.41$ & 9,212 & 498 & 2,693 \\
Labor cost per ha (thousand VND) & $5,060.35$ & 9,657 & 232 & 5,373 \\
\hline
\end{tabular}


Table A2. Cont.

\begin{tabular}{|c|c|c|c|c|}
\hline Item & Mean & Max & Min & Std. Dev. \\
\hline \multicolumn{5}{|c|}{ Salinized area $(n=37)$} \\
\hline Area (ha) & 1.32 & 5.50 & 0.30 & 1.02 \\
\hline Yield (kg/ha) & $1,046.35$ & 2,300 & 300 & 427.82 \\
\hline Rate of male shrimp (\%) & 52.41 & 90 & 31 & 16.02 \\
\hline Average density per $\mathrm{m}^{2}$ (shrimp) & 15.84 & 25 & 7 & 5.01 \\
\hline Fish food $(\mathrm{kg} / \mathrm{ha})$ & 3.45 & 7.40 & 0.79 & 1.47 \\
\hline Costs: & $77,786.73$ & & & \\
\hline - Dam cost per ha (thousand VND) & $10,269.49$ & 45,346 & 1,104 & 9,152 \\
\hline - Seed cost per ha (thousand VND) & $19,317.70$ & 33,692 & 1,715 & 8,437 \\
\hline - Food cost per ha (thousand VND) & $38,372.03$ & 77,871 & 737 & 24,452 \\
\hline - Chemical cost per ha (thousand VND) & $4,913.76$ & 9,212 & 246 & 2,871 \\
\hline - Labor cost per ha (thousand VND) & $4,913.76$ & 9,571 & 232 & 2,841 \\
\hline \multicolumn{5}{|c|}{ Fresh area $(n=42)$} \\
\hline Area (ha) & 1.33 & 13.00 & 0.30 & 2.02 \\
\hline Yield (kg/ha) & $1,248.55$ & 3,500 & 490 & 574.12 \\
\hline Rate of male shrimp (\%) & 54.67 & 85 & 7 & 14.03 \\
\hline Average density per $\mathrm{m}^{2}$ (shrimp) & 13.02 & 25 & 7 & 4.57 \\
\hline Fish food (kg/ha) & 3.021667 & 7.4 & 0.99 & 1.49 \\
\hline Costs: & $66,119.71$ & & & \\
\hline - Dam cost per ha (thousand VND) & 9372.262 & 34,125 & 589 & 7,699 \\
\hline - Seed cost per ha (thousand VND) & 15205.71 & 34,365 & 2,855 & 7,889 \\
\hline - Food cost per ha (thousand VND) & 31553.45 & 75,332 & 1,031 & 22,390 \\
\hline - Chemical cost per ha (thousand VND) & 4994.143 & 9,207 & 498 & 2,559 \\
\hline - Labor cost per ha (thousand VND) & 4994.143 & 9,657 & 322 & 2,757 \\
\hline
\end{tabular}

Table A3. OLS estimation of rice production function with salinity impact, dependent variable: yield (kg/ha).

\begin{tabular}{ccc}
\hline Variable & Without Interaction Effect & With Interaction Effect \\
\hline Constant & $8466.04 *$ & $7765.0988 *$ \\
Seed $(\mathrm{kg} / \mathrm{ha})$ & 0.806 & 1.4860 \\
Labor $(\mathrm{day} / \mathrm{ha})$ & $-6.651 * * *$ & $29.79169 * *$ \\
Fertilizer $(\mathrm{kg} / \mathrm{ha})$ & 0.073 & -0.1539 \\
Salinity $($ Dummy $)$ & $-1325.49 *$ & -1.7762 \\
Salinity $*$ Seed & & $-15.1224 * * *$ \\
Salinity $*$ Labor & & 0.1230 \\
Salinity $*$ Fertilizer & & 0.0004 \\
Seed $*$ Seed & & $-0.37265 * *$ \\
Labor $*$ Labor & & 0.0001 \\
Fertilizer $*$ & & 0.4657 \\
Fertilizer & 0.443 & $19.3416 *$ \\
R-Square & $45.2938 *$ & \\
F-test & &
\end{tabular}

Note: \# 1 if salinized; otherwise $0 ; *, * *, * * *$ significant at $1 \%, 5 \%, 10 \%$ respectively. 
Table A4. OLS estimation of aquaculture production function with salinity impact, dependent variable: yield $(\mathrm{kg} / \mathrm{ha})$.

\begin{tabular}{ccc}
\hline Variable & Without Interaction Effect & With Interaction Effect \\
\hline Constant & $939.545 * * *$ & $1282.741 *$ \\
Area $($ ha) & $-16.829 * *$ & $-24.246 * *$ \\
Male rate $(\%)$ & 4.077 & -5.921 \\
Density $\left(\right.$ shrimp per m ${ }^{2}$ ) & $-13.044 * *$ & $9.043 * *$ \\
Food (tonne) & $12.588 * *$ & 51.130 \\
Dam cost (thousand VND per ha) & -0.009 & \\
Seed cost (thousand VND per ha) & 0.006 & \\
Food cost (thousand VND per ha) & $0.002 * *$ & \\
Chemical cost (thousand VND per ha) & 0.026 & \\
Labor cost (thousand VND per ha) & 0.007 & 27.969 \\
Salinity (dummy) \# & $-183.643 * *$ & -24.377 \\
Experience $($ year) & $43.351 * *$ & 0.002 \\
Education (year) & -15.884 & $13.004 * *$ \\
Total cost (thousand VND per ha) & & $-37.029 * * *$ \\
Salinity $*$ male rate & & $-85.33 * *$ \\
Salinity $*$ density & & $-0.001 * *$ \\
Salinity $*$ food & & 0.195 \\
Salinity $*$ total cost & & $47.4721 *$ \\
R Square & 0.150 & \\
F-test & $45.9707 *$ &
\end{tabular}

Note: \# 1 if salinized; otherwise $0 ; *, * *, * * *$ significant at $1 \%, 5 \%, 10 \%$ respectively.

Table A5. GDP forecasts of GDP values and rice and aquaculture areas, 2010-2110.

\begin{tabular}{cccccccccccc}
\hline Forecast Value & $\mathbf{2 0 1 0}$ & $\mathbf{2 0 2 0}$ & $\mathbf{2 0 3 0}$ & $\mathbf{2 0 4 0}$ & $\mathbf{2 0 5 0}$ & $\mathbf{2 0 6 0}$ & $\mathbf{2 0 7 0}$ & $\mathbf{2 0 8 0}$ & $\mathbf{2 0 9 0}$ & $\mathbf{2 1 0 0}$ & $\mathbf{2 1 1 0}$ \\
\hline $\begin{array}{c}\text { GDP } \\
\text { (billion USD) }\end{array}$ & 0.65 & 2.02 & 5.24 & 13.58 & 26.72 & 52.56 & 103.39 & 203.38 & 301.05 & 445.6 & 659.6 \\
$\begin{array}{c}\text { Annual increase } \\
\text { in GDP (\%) }\end{array}$ & 12 & 12 & 10 & 10 & 7 & 7 & 7 & 7 & 4 & 4 & 4 \\
$\begin{array}{c}\text { Rice area (ha) } \\
\text { Aqua-culture } \\
\text { area (ha) }\end{array}$ & 90,000 & 89,000 & 89,000 & 89,000 & 89,000 & 87,000 & 87,000 & 87,000 & 87,000 & 85,000 & 85,000 \\
$\quad \begin{array}{c}\text { In which: } \\
\text { Fresh-water areas }\end{array}$ & 10,000 & 15,000 & 15,000 & 15,000 & 15,000 & 15,000 & 15,000 & 15,000 & 15,000 & 15,000 & 15,000 \\
\hline
\end{tabular}

Note: Forecasts for 2010-2020 are from Tra Vinh province's 2020 Socio-economic Master Plan [4]. 
Table A6. Decomposition of dike construction and maintenance costs (per $\mathrm{km}$ ) in rural Vietnam. Source: Hillen et al. [10].

\begin{tabular}{ccccccccccc}
\hline \multirow{2}{*}{ Cost Category } & \multicolumn{3}{c}{ Height at $2 \mathbf{~ m}$} & \multicolumn{3}{c}{ Height at 3 m } & \multicolumn{3}{c}{ Height at 4 m } \\
\cline { 2 - 11 } & \multicolumn{2}{c}{ Hillen } & Mai & \multicolumn{2}{c}{ Hillen } & Mai & Hillen & Mai \\
\cline { 2 - 11 } & $(\mathrm{M} €)$ & $(\mathrm{M} \$)$ & $(\mathrm{M} \$)$ & $(\mathrm{M} €)$ & $(\mathrm{M} \$)$ & $(\mathrm{M} \$)$ & $(\mathrm{M} €)$ & $(\mathrm{M} \$)$ & $(\mathrm{M} \$)$ \\
\hline Dike body & 0.286 & 0.386 & 0.92 & 0.471 & 0.636 & 1.38 & 0.729 & 0.984 & 2.00 \\
Land use & 0.071 & 0.096 & 0.31 & 0.229 & 0.309 & 0.72 & 0.400 & 0.540 & 1.00 \\
Berm & 0.014 & 0.019 & - & 0.014 & 0.019 & - & 0.014 & 0.019 & - \\
Revetment & 0.486 & 0.656 & - & 0.714 & 0.964 & - & 0.929 & 1.254 & - \\
Outer/inter protection & - & - & 0.57 & - & - & 0.58 & - & - & 0.71 \\
Maintenance & - & - & 0.02 & - & - & 0.02 & - & - & 0.04 \\
Total cost & 0.857 & 1.157 & 1.82 & 1.429 & 1.929 & 2.70 & 2.071 & 2.796 & 3.75 \\
\hline
\end{tabular}

Table A7. Unit cost prices of dike heightening (USD/km). Source: Hillen et al. [10].

\begin{tabular}{cc}
\hline Type of Coastal Defense Measure & $\begin{array}{c}\text { Unit Cost IPCC CZMS (1990) } \\
\text { (2009 Price Level, USD) }\end{array}$ \\
\hline New 1-m-high sea dike & 0.55 \\
New 1-m-high sea dike with regular maintenance & 0.84 \\
Raising low sea dike by 1 m in rural areas & 0.70 \\
Raising high sea dike by 1 m in rural areas & 1.40 \\
Raising sea dike by 1 m in urban areas & 14.03 \\
\hline
\end{tabular}

Table A8. Simulation results, dike costs, CBA analysis.

\begin{tabular}{lccccc}
\hline Cost Component & Distribution & Min Value & Max Value & Simulated Value & Skewness \\
\hline Construction cost & & & & & \\
- 2m high dike & Uniform & 1.16 & 1.82 & 1.49 & 0 \\
- 3m high dike & Uniform & 1.93 & 2.7 & 2.31 & 0 \\
- 4m high dike & Uniform & 2.8 & 3.75 & 3.27 & 0 \\
Maintenance cost & Uniform & 0.027 & 0.04 & 0.3 & 0 \\
Heightening cost & & & & & \\
- By 1m & Uniform & 0.702 & 1.404 & 1.05 & 0 \\
- By 2m & Uniform & 1.41 & 2.81 & 2.11 & 0 \\
\hline \multicolumn{7}{r}{ Note: Corresponding minimum/maximum values are drawn from Tables A5-A10. }
\end{tabular}

Table A9. Costs of dike options (million USD).

\begin{tabular}{cccccccc}
\hline Cost Category by Option & $\mathbf{2 0 1 0}$ & $\mathbf{2 0 2 0}$ & $\mathbf{2 0 3 0}$ & $\mathbf{2 0 4 0}$ & $\mathbf{2 0 5 0}$ & $\mathbf{2 0 6 0}$ & $\mathbf{2 1 1 0}$ \\
\hline Option 1 & 221.97 & 2.94 & 2.94 & 2.94 & 2.94 & 221.97 & 2.94 \\
- Construction cost & 219.03 & 0 & 0 & 0 & 0 & 219.03 & 0 \\
- Maintenance cost & 2.94 & 2.94 & 2.94 & 2.94 & 2.94 & 2.94 & 2.94 \\
- Heightening cost & 0 & 0 & 0 & 0 & 0 & 0 & 0 \\
Option 2 & 5.25 & 2.94 & 2.94 & 2.94 & 2.94 & 2.94 & 2.94 \\
- Construction cost & 2.31 & 0 & 0 & 0 & 0 & 0 & 0 \\
- Maintenance cost & 2.94 & 2.94 & 2.94 & 2.94 & 2.94 & 2.94 & 2.94 \\
- Heightening cost & 0 & 0 & 0 & 0 & 0 & 0 & 0 \\
\hline
\end{tabular}


Table A9. Cont.

\begin{tabular}{lccccccc}
\hline Cost Category by Option & $\mathbf{2 0 1 0}$ & $\mathbf{2 0 2 0}$ & $\mathbf{2 0 3 0}$ & $\mathbf{2 0 4 0}$ & $\mathbf{2 0 5 0}$ & $\mathbf{2 0 6 0}$ & $\mathbf{2 1 1 0}$ \\
\hline Option 3 & 221.97 & 2.94 & 157.29 & 2.94 & 2.94 & 2.94 & 2.94 \\
- Construction cost & 219.03 & 0 & 0 & 0 & 0 & 0 & 0 \\
- Maintenance cost & 2.94 & 2.94 & 2.94 & 2.94 & 2.94 & 2.94 & 2.94 \\
- Heightening cost & 0 & 0 & 154.35 & 0 & 0 & 0 & 0 \\
Option 4 & 486.57 & 5.88 & 5.88 & 5.88 & 5.88 & 5.88 & 5.88 \\
- Construction cost & 480.69 & 0 & 0 & 0 & 0 & 0 & 0 \\
- Maintenance cost & 5.88 & 5.88 & 5.88 & 5.88 & 5.88 & 5.88 & 5.88 \\
- Heightening cost & 0 & 0 & 0 & 0 & 0 & 0 & 0 \\
Option 5 & 221.97 & 2.94 & 313.11 & 5.88 & 5.88 & 5.88 & 5.88 \\
- Construction cost & 219.03 & 0 & 0 & 0 & 0 & 0 & 0 \\
- Maintenance cost & 2.94 & 2.94 & 2.94 & 5.88 & 5.88 & 5.88 & 5.88 \\
- Heightening cost & 0 & 0 & 310.17 & 0 & 0 & 0 & 0 \\
\hline
\end{tabular}

Note: Maintenance cost is yearly annuity cash flow.

Table A10. Benefits of dike options (unit: million USD).

\begin{tabular}{|c|c|c|c|c|c|c|c|c|c|c|c|}
\hline $\begin{array}{c}\text { Benefit } \\
\text { Category by } \\
\text { Option }\end{array}$ & 2010 & 2020 & 2030 & 2040 & 2050 & 2060 & 2070 & 2080 & 2090 & 2100 & 2110 \\
\hline Option 1 & 36.7 & 129.7 & 842.9 & 688.4 & $4,151.0$ & $2,558.8$ & $15,958.3$ & $9,799.3$ & $46,398.7$ & $21,427.0$ & $101,620.6$ \\
\hline - Storm & 0.0 & 10.1 & 581.2 & 68.0 & $2,965.7$ & 263.0 & $11,476.2$ & $1,017.7$ & $33,417.2$ & 2,229.9 & $73,221.3$ \\
\hline - Flood & 3.9 & 86.8 & 225.2 & 584.0 & $1,148.8$ & $2,259.9$ & $4,445.6$ & $8,745.1$ & $12,944.9$ & $19,161.7$ & $28,364.0$ \\
\hline - Salinity & 32.8 & 32.8 & 36.5 & 36.5 & 36.5 & 35.9 & 36.5 & 36.5 & 36.5 & 35.4 & 35.4 \\
\hline Option 2 & 36.7 & 129.7 & 842.9 & 688.4 & $4,151.0$ & $5,712.2$ & $15,958.3$ & $9,799.3$ & $46,398.7$ & $21,427.0$ & $141,198.2$ \\
\hline - Storm & 0.0 & 10.1 & 581.2 & 68.0 & $2,965.7$ & $1,682.0$ & $11,476.2$ & $1,017.7$ & $33,417.2$ & $2,229.9$ & $91,031.2$ \\
\hline - Flood & 3.9 & 86.8 & 225.2 & 584.0 & $1,148.8$ & $3,994.3$ & $4,445.6$ & $8,745.1$ & $12,944.9$ & $19,161.7$ & $50,131.7$ \\
\hline - Salinity & 32.8 & 32.8 & 36.5 & 36.5 & 36.5 & 35.9 & 36.5 & 36.5 & 36.5 & 35.4 & 35.4 \\
\hline Option 3 & 36.7 & 129.7 & 842.9 & 688.4 & $4,151.0$ & $5,712.2$ & $15,958.3$ & $9,799.3$ & $46,398.7$ & $21,427.0$ & $141,198.2$ \\
\hline - Storm & 0.0 & 10.1 & 581.2 & 68.0 & $2,965.7$ & $1,682.0$ & $11,476.2$ & $1,017.7$ & $33,417.2$ & 2,229.9 & $91,031.2$ \\
\hline - Flood & 3.9 & 86.8 & 225.2 & 584.0 & $1,148.8$ & $3,994.3$ & $4,445.6$ & $8,745.1$ & $12,944.9$ & $19,161.7$ & $50,131.7$ \\
\hline - Salinity & 32.8 & 32.8 & 36.5 & 36.5 & 36.5 & 35.9 & 36.5 & 36.5 & 36.5 & 35.4 & 35.4 \\
\hline Option 4 & 36.7 & 129.7 & 842.9 & 688.4 & $4,151.0$ & $5,712.2$ & $15,958.3$ & $9,799.3$ & $46,398.7$ & $21,427.0$ & $185,393.3$ \\
\hline - Storm & 0.0 & 10.1 & 581.2 & 68.0 & $2,965.7$ & $1,682.0$ & $11,476.2$ & $1,017.7$ & $33,417.2$ & $2,229.9$ & $110,820.0$ \\
\hline - Flood & 3.9 & 86.8 & 225.2 & 584.0 & $1,148.8$ & $3,994.3$ & $4,445.6$ & $8,745.1$ & $12,944.9$ & $19,161.7$ & $74,537.9$ \\
\hline - Salinity & 32.8 & 32.8 & 36.5 & 36.5 & 36.5 & 35.9 & 36.5 & 36.5 & 36.5 & 35.4 & 35.4 \\
\hline Option 5 & 36.7 & 129.7 & 842.9 & 688.4 & $4,151.0$ & $5,712.2$ & $15,958.3$ & $9,799.3$ & $46,398.7$ & $21,427.0$ & $185,393.3$ \\
\hline - Storm & 0.0 & 10.1 & 581.2 & 68.0 & $2,965.7$ & $1,682.0$ & $11,476.2$ & $1,017.7$ & $33,417.2$ & $2,229.9$ & $110,820.0$ \\
\hline - Flood & 3.9 & 86.8 & 225.2 & 584.0 & $1,148.8$ & $3,994.3$ & $4,445.6$ & $8,745.1$ & $12,944.9$ & $19,161.7$ & $74,537.9$ \\
\hline - Salinity & 32.8 & 32.8 & 36.5 & 36.5 & 36.5 & 35.9 & 36.5 & 36.5 & 36.5 & 35.4 & 35.4 \\
\hline
\end{tabular}

Note: Losses due to salinity avoided is yearly annuity cash flow.

(C) 2014 by the authors; licensee MDPI, Basel, Switzerland. This article is an open access article distributed under the terms and conditions of the Creative Commons Attribution license (http://creativecommons.org/licenses/by/3.0/). 